\title{
Rescue of the skeletal phenotype in CasR-deficient mice by transfer onto the Gcm 2 null background
}

\author{
Qisheng Tu, ${ }^{1}$ Min Pi, ${ }^{1}$ Gerard Karsenty, ${ }^{2}$ Leigh Simpson, ${ }^{1}$ Shiguang Liu, ${ }^{1}$ \\ and L. Darryl Quarles ${ }^{1}$
}

${ }^{1}$ Center for Bone and Mineral Disorders, Duke University Medical Center, Durham, North Carolina, USA

${ }^{2}$ Molecular and Human Genetics, Baylor College of Medicine, Houston, Texas, USA

\begin{abstract}
To understand the role of the calcium-sensing receptor (CasR) in the skeleton, we used a genetic approach to ablate parathyroid glands and remove the confounding effects of elevated parathyroid hormone (PTH) in CasR-deficient mice. CasR deficiency was transferred onto the glial cells missing 2-deficient (Gcm2deficient) background by intercrossing Cas $R$ - and $\mathrm{Gcm} 2$-deficient mice. Superimposed Gcm 2 deficiency rescued the perinatal lethality in CasR-deficient mice in association with ablation of the parathyroid glands and correction of the severe hyperparathyroidism. In addition, the double homozygous Cas $R$-and Gcm2-deficient mice demonstrated healing of the abnormal mineralization of cartilage and bone associated with CasR deficiency, indicating that rickets and osteomalacia in CasR-deficient mice are not due to an independent function of Cas $R$ in bone and cartilage but to the effect of severe hyperparathyroidism in the neonate. Analysis of the skeleton of 6-week-old homozygous Cas $R$ - and $\mathrm{Gcm} 2$-deficient mice also failed to identify any essential, nonredundant role for Cas $R$ in regulating chondrogenesis or osteogenesis, but further studies are needed to establish the function of Cas $R$ in the skeleton. In contrast, concomitant $\mathrm{Gcm} 2$ and Cas $R$ deficiency failed to rescue the hypocalciuria in Cas $R$-deficient mice, consistent with direct regulation of urinary calcium excretion by CasR in the kidney. Double Gcm2- and CasR-deficient mice provide an important model for evaluating the extraparathyroid functions of Cas $R$.
\end{abstract}

J. Clin. Invest. 111:1029-1037 (2003). doi:10.1172/JCI200317054.

\section{Introduction}

The heptahelical extracellular calcium-sensing receptor (CasR) plays a central role in controlling systemic calcium homeostasis, predominately through its effects on regulation of parathyroid hormone (PTH) secretion by the parathyroid glands and urinary calcium excretion by the kidney (1-4). Cas $R$ also is widely expressed in many other tissues, including bone and cartilage, where its biological function has not been established $(1,5-7)$. Whether CasR has a direct role in regulating bone and cartilage function is a subject of much debate. In vitro studies and indirect in vivo evidence implicate CasR or a related receptor in the regulation of important steps in osteoblast-mediated bone formation, as well as in the differentiation and mineralization of cartilage (5-10). Consistent with the role of CasR in mineralization of

Received for publication October 3, 2002, and accepted in revised form January 21, 2003.

Address correspondence to: L. Darryl Quarles, Center for Bone and Mineral Disorders, PO Box 3036, Duke University Medical Center, Durham, North Carolina 27710, USA.

Phone: (919) 660-6855; Fax: (919) 684-4476;

E-mail: quarl001@mc.duke.edu.

Conflict of interest: The authors have declared that no conflict of interest exists.

Nonstandard abbreviations used: calcium-sensing receptor (CasR); parathyroid hormone (PTH); glial cells missing 2 (Gcm2); deoxypyridinoline (Dpd); bone mineral density (BMD); dualenergy X-ray absorptiometry (DEXA); neonatal severe hyperparathyroidism (NSHPT). bone and cartilage, rickets and osteomalacia were the major skeletal abnormalities found in CasR-deficient mice (11). The hyperparathyroidism, hypercalcemia, and hypophosphatemia that accompany deletion of Cas $R$ from the parathyroid glands, however, confound the independent assessment of CasR effects on bone and cartilage. The neonatal mortality in CasR-deficient mice also prevents assessment of the role of Cas $R$ in the adult skeleton (11). In addition, CasR transcripts have been inconsistently detected in mineralized bone containing mature osteoblasts and osteocytes after removal of marrow elements (11). Moreover, the putative osteoblastic cation-sensing receptor is characterized by different cation specificity from Cas $R$, namely failing to respond to calcimimetics or magnesium (12-15), and osteoblasts derived from CasR-deficient mice retain their ability to respond to extracellular calcium through a $G$ protein-coupled mechanism, suggesting that the osteoblastic receptor is distinct from CasR (14).

Regardless, a full understanding of the direct effect of CasR on bone and cartilage function requires correction of the hyperparathyroidism that accompanies Cas $R$ deficiency. Surgical parathyroidectomy is not technically feasible in neonatal mice. Although transfer of CasR deficiency onto PTH- or PTH receptor-deficient mice provides a means to remove the effects of excess PTH (16), the complete loss of PTH signaling leads to dysmorphic skeletons that might mask potential independent effects of CasR (17). Deletion of glial cells missing 2 
Table 1

Data from 1-week-old mice

\begin{tabular}{|c|c|c|c|c|c|c|c|c|}
\hline \multicolumn{2}{|l|}{ Group } & I & II & III & IV & V & $\mathrm{VI}$ & $P$ value \\
\hline Genotype & $\begin{array}{l}\text { CasR } \\
\text { Gcm }\end{array}$ & $\begin{array}{c}+/+ \\
+/+ \text { or }+/-\end{array}$ & $\begin{array}{c}-/- \\
+/+ \text { or }+/-\end{array}$ & $\begin{array}{l}+/+ \\
-/-\end{array}$ & $\begin{array}{l}-/- \\
-/-\end{array}$ & $\begin{array}{c}+/- \\
+/+ \text { or }+/-\end{array}$ & $\begin{array}{l}+/- \\
-1-\end{array}$ & \\
\hline \multicolumn{9}{|c|}{ Serum values } \\
\hline \multicolumn{2}{|c|}{ PTH (pg/ml) } & $\begin{array}{c}13 \pm 1.5^{\mathrm{A}} \\
(n=16)\end{array}$ & $\begin{array}{c}361 \pm 54^{\mathrm{B}} \\
(n=20)\end{array}$ & $\begin{array}{c}9 \pm 2.4^{\mathrm{A}} \\
(n=7)\end{array}$ & $\begin{array}{l}9 \pm 1.5^{\mathrm{A}} \\
(n=11)\end{array}$ & $\begin{array}{l}15 \pm 2^{\mathrm{A}} \\
(n=22)\end{array}$ & $\begin{array}{c}8 \pm 2^{\mathrm{A}} \\
(n=10)\end{array}$ & $<0.001$ \\
\hline \multicolumn{2}{|c|}{ Calcium (mg/dl) } & $\begin{array}{c}7.7 \pm 0.4^{\mathrm{B}} \\
(n=16)\end{array}$ & $\begin{array}{c}14.5 \pm 0.9^{c} \\
(n=16)\end{array}$ & $\begin{array}{c}5.7 \pm 0.4^{\mathrm{A}} \\
(n=7)\end{array}$ & $\begin{array}{c}5.8 \pm 0.3^{\mathrm{A}} \\
(n=11)\end{array}$ & $\begin{array}{c}7.8 \pm 0.2^{B} \\
(n=22)\end{array}$ & $\begin{array}{c}5.7 \pm 0.4^{\mathrm{A}} \\
(n=10)\end{array}$ & $<0.001$ \\
\hline \multicolumn{2}{|c|}{ Phosphorus (mg/dl) } & $\begin{array}{c}11.5 \pm 0.6^{\mathrm{B}} \\
(n=15)\end{array}$ & $\begin{array}{c}4.9 \pm 0.5^{\mathrm{A}} \\
(n=11)\end{array}$ & $\begin{array}{c}13.9 \pm 0.7 c \\
(n=7)\end{array}$ & $\begin{array}{c}14.7 \pm 0.7 \mathrm{C} \\
(n=9)\end{array}$ & $\begin{array}{c}11.0 \pm 0.5^{\mathrm{B}} \\
(n=24)\end{array}$ & $\begin{array}{c}14.0 \pm 1^{C} \\
(n=9)\end{array}$ & $<0.001$ \\
\hline \multicolumn{2}{|c|}{ Osteocalcin (ng/ml) } & $\begin{array}{c}511 \pm 35^{\mathrm{A}} \\
(n=10)\end{array}$ & $\begin{array}{c}783 \pm 73^{B} \\
(n=9)\end{array}$ & $\begin{array}{c}498 \pm 57^{A} \\
(n=4)\end{array}$ & $\begin{array}{c}483 \pm 19^{\mathrm{A}} \\
(n=4)\end{array}$ & $\begin{array}{c}531 \pm 50^{\mathrm{A}} \\
(n=11)\end{array}$ & $\begin{array}{c}471 \pm 100^{A} \\
(n=4)\end{array}$ & 0.004 \\
\hline \multicolumn{9}{|c|}{ Urine values } \\
\hline \multicolumn{2}{|c|}{ Dpd/creatinine ratio } & $\begin{array}{l}57 \pm 4^{\mathrm{A}} \\
(n=10)\end{array}$ & $\begin{array}{l}88 \pm 8^{\mathrm{B}} \\
(n=7)\end{array}$ & $\begin{array}{l}61 \pm 8^{\mathrm{A}} \\
(n=5)\end{array}$ & $\begin{array}{c}53 \pm 8^{\mathrm{A}} \\
(n=6)\end{array}$ & $\begin{array}{l}54 \pm 7^{A} \\
(n=10)\end{array}$ & $\begin{array}{c}57 \pm 7^{\mathrm{A}} \\
(n=5)\end{array}$ & 0.009 \\
\hline \multicolumn{2}{|c|}{ Calcium/creatinine ratio } & $\begin{array}{c}0.71 \pm 0.06^{C} \\
(n=13)\end{array}$ & $\begin{array}{c}0.35 \pm 0.03^{\mathrm{A}} \\
(n=17)\end{array}$ & $\begin{array}{c}0.81 \pm 15^{c} \\
(n=6)\end{array}$ & $\begin{array}{c}0.45 \pm 0.05^{A, B} \\
(n=12)\end{array}$ & $\begin{array}{c}0.53 \pm 0.07^{\mathrm{B}} \\
(n=14)\end{array}$ & $\begin{array}{c}0.46 \pm 0.05^{\mathrm{A}, \mathrm{B}} \\
(n=9)\end{array}$ & $<0.001$ \\
\hline \multicolumn{9}{|c|}{ Structural parameters } \\
\hline \multicolumn{2}{|c|}{ Body weight (g) } & $\begin{array}{c}5.2 \pm 0.1^{\mathrm{A}} \\
(n=33)\end{array}$ & $\begin{array}{c}1.7 \pm 0.1^{\mathrm{B}} \\
(n=18)\end{array}$ & $\begin{array}{c}5.0 \pm 0.1^{\mathrm{A}} \\
(n=13)\end{array}$ & $\begin{array}{c}5.1 \pm 0.2^{\mathrm{A}} \\
(n=14)\end{array}$ & $\begin{array}{c}5.1 \pm 0.08^{\mathrm{A}} \\
(n=88)\end{array}$ & $\begin{array}{c}5.0 \pm 0.2^{\mathrm{A}} \\
(n=22)\end{array}$ & $<0.001$ \\
\hline \multicolumn{2}{|c|}{ Body length (mm) } & $\begin{array}{c}63.7 \pm 1.2^{\mathrm{A}} \\
(n=10)\end{array}$ & $\begin{array}{c}49.4 \pm 0.5^{\mathrm{B}} \\
(n=9)\end{array}$ & $\begin{array}{c}62.0 \pm 0.8^{\mathrm{A}} \\
(n=7)\end{array}$ & $\begin{array}{c}61.7 \pm 1.0^{\mathrm{A}} \\
(n=7)\end{array}$ & $\begin{array}{c}63.9 \pm 1.0^{\mathrm{A}} \\
(n=23)\end{array}$ & $\begin{array}{c}63.7 \pm 1.1^{\mathrm{A}} \\
(n=6)\end{array}$ & $<0.001$ \\
\hline \multicolumn{2}{|c|}{ Femur length (mm) } & $\begin{array}{c}4.2 \pm 0.8^{\mathrm{A}} \\
(n=10)\end{array}$ & $\begin{array}{c}2.61 \pm 1.7^{\mathrm{B}} \\
(n=9)\end{array}$ & $\begin{array}{c}4.3 \pm 0.4^{\mathrm{A}} \\
(n=7)\end{array}$ & $\begin{array}{c}4.2 \pm 0.7^{\mathrm{A}} \\
(n=7)\end{array}$ & $\begin{array}{c}4.3 \pm 0.7^{\mathrm{A}} \\
(n=23)\end{array}$ & $\begin{array}{c}4.3 \pm 0.6^{\mathrm{A}} \\
(n=6)\end{array}$ & $<0.001$ \\
\hline \multicolumn{2}{|c|}{ Mineralized vertebrae (no.) } & $\begin{array}{c}26.4 \pm 0.3^{\mathrm{A}} \\
(n=10)\end{array}$ & $\begin{array}{c}13.2 \pm 0.3^{\mathrm{B}} \\
(n=9)\end{array}$ & $\begin{array}{c}26.6 \pm 0.2^{\mathrm{A}} \\
(n=7)\end{array}$ & $\begin{array}{c}26.3 \pm 0.3^{\mathrm{A}} \\
(n=7)\end{array}$ & $\begin{array}{c}25.8 \pm 0.3^{\mathrm{A}} \\
(n=23)\end{array}$ & $\begin{array}{c}26.7 \pm 0.2^{\mathrm{A}} \\
(n=6)\end{array}$ & $<0.001$ \\
\hline \multicolumn{2}{|c|}{ Bone ash (\% dry wt) } & $\begin{array}{c}31.9 \pm 1.8^{\mathrm{A}} \\
(n=18)\end{array}$ & $\begin{array}{c}23.8 \pm 1.6^{\mathrm{B}} \\
(n=14)\end{array}$ & $\begin{aligned} 33.9 & \pm 3.0^{\mathrm{A}} \\
(n & =7)\end{aligned}$ & $\begin{array}{c}32.0 \pm 1.9^{\mathrm{A}} \\
(n=10)\end{array}$ & $\begin{array}{c}32.5 \pm 1.7^{\mathrm{A}} \\
(n=29)\end{array}$ & $\begin{array}{c}31.8 \pm 1.2^{\mathrm{A}} \\
(n=11)\end{array}$ & 0.013 \\
\hline
\end{tabular}

Values represent mean \pm SEM of the number of animals per group as indicated in parentheses. Dpd, deoxypyridinoline; $\mathrm{PTH}$, parathyroid hormone. $\mathrm{A}, \mathrm{B}, \mathrm{C}$ Indicates significant differences between groups for the indicated parameter. Values sharing the same superscript in a given category are not significantly different, whereas values with a different superscript are significantly different at indicated $P$ values at the end of the row. Group I, wild-type and heterozygous $\mathrm{Gcm}^{+/-}$; Group II, homozygous CasR $R^{-/}$and mixed homozygous CasR $R^{-/} /$heterozygous $\mathrm{Gcm} 2^{+/-}$; Group III, homozygous $\mathrm{Gcm2} 2^{-/-}$; Group IV, double homozygous

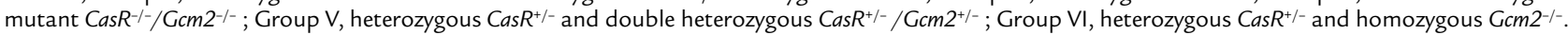

(Gcm2), a mouse homologue of Drosophila Gcm, is a master regulatory gene of parathyroid gland development and provides an alternative strategy for achieving a molecular parathyroidectomy (18). Gcm2-deficient mice lack parathyroid glands but exhibit mild hypoparathyroidism due to the auxiliary production of PTH as well as normal skeletal growth and development (19).

In the current study, we transferred CasR deficiency onto the $\mathrm{Gcm} 2$-deficient background to create a model to assess the independent function of CasR in bone and cartilage and the importance of Cas $R$ beyond the early postnatal period. Molecular ablation of parathyroid glands and rescue of the perinatal lethality was achieved in double homozygous CasR-and Gcm2-deficient mice. Correction of the severe hyperparathyroidism prevented the rickets and osteomalacia in CasR-deficient mice but did not rescue the hypocalciuria. In addition, analysis of the skeleton of homozygous CasR-and Gcm2-deficient mice failed to identify any essential, nonredundant role for Cas $R$ in regulating growth-plate and bone mineralization. These studies indicate that defective mineralization of bone and cartilage is due to metabolic abnormalities associated with hyperparathyroidism rather than the absence of skeletal Cas $R$ and establish that the low urinary calcium is mediated by the absence of CasR in the kidney.

\section{Methods}

Creation of double CasR- and Gcm2-deficient mice. We obtained heterozygous mice $\left(\mathrm{CasR}^{+/}\right)$with targeted disruptions of exon 5 of the CasR gene from the laboratory of David Conner (Harvard University, Boston, Massachusetts, USA) (20). These mice were bred and maintained on a Black Swiss/129SvJ background. CasR-deficient mice express nonfunctional Cas $R$ splice variants lacking exon 5 , thereby creating a functional Cas $R$ knockout (21). We obtained heterozygous $\mathrm{Gcm} 2^{+/-}$mice, which have the targeted replacement of all four exons of the $\mathrm{Gcm} 2$ gene, from the Baylor College of Medicine (19). $\mathrm{Gcm}^{+/-}$mice had been bred in a C57BL/6J/129SvEv background. Mice were maintained and used in accordance with the guidelines established by the Institutional Animal Care and Use Committee of Duke University.

We created double heterozygous CasR-and Gcm2-deficient mice on a mixed genetic background by inbreeding $\mathrm{CasR}^{+/-}$and $\mathrm{Gcm}^{+/-}$mice for two generations. Crosses between $\mathrm{Cas}^{+/-}$and $\mathrm{Gcm}^{+/-}$mice produced double heterozygous $\mathrm{CasR}^{+/-} / \mathrm{Gcm}^{+/-}$mice. Male and female F2 $\mathrm{Cas}^{+/-} / \mathrm{Gcm} 2^{+/-}$mice were mated to generate nine distinct genotypes: $\mathrm{CasR}^{+/+} / \mathrm{Gcm}^{+/+}, \mathrm{CasR}^{+/-} / \mathrm{Gcm}^{+/-}$, $\mathrm{CasR}^{-/-} / \mathrm{Gcm}_{2-/-}, \quad \mathrm{CasR}^{+/-} / \mathrm{Gcm}^{+/+}, \quad \mathrm{CasR}^{+/+} / \mathrm{Gcm}^{+/-}$, $\mathrm{CasR}^{-/-} / \mathrm{Gcm}^{+/+}$, $\mathrm{CasR}^{+/+} / \mathrm{Gcm}^{-/-}$, $\mathrm{CasR}^{+/-} / \mathrm{Gcm}^{-/-}$, and $\mathrm{CasR}^{-1-} / \mathrm{Gcm}^{+/-}$. This report focuses on results obtained 
from the analysis of $\mathrm{F} 3$ generation littermates. We found that heterozygous $\mathrm{Gcm}^{+/-}$mice were identical to wild-type mice in all parameters tested. In addition, the absence of one $\mathrm{Gcm} 2$ allele did not influence the phenotype of either heterozygous $\mathrm{Cas}^{+/-}$or homozygous Cas $\mathrm{R}^{-/-}$mice. This allowed the $\mathrm{Gcm} 2^{+/-}$mice to be combined with their wild-type counterparts to create six groups with distinct phenotypes, as defined in Table 1.

Genotyping. Genomic DNA tissue was extracted and purified from the tail of each mouse using a QIAGEN DNeasy Tissue kit (QIAGEN Inc., Valencia, California, USA). To detect the presence of CasR $R^{-/}$, we performed PCR using the reverse primer CasR2144.R ( $5^{\prime}$-TGAAGCACCTACGGCACCTG-3'), specific for the native mouse $C a s R$ gene sequence, in combination with a primer designed for upstream elements in exon 5, CasR1956.F (5'-TGATGAAGAGTCTTTCTCGG-3'), or primer KCM-F (5'TCTTGATTCCCACTTTGTGGTTCTA- $3^{\prime}$ ) for the inserted neomycin gene sequence used for targeted disruption of exon 5 (previously named exon 4). To genotype Gcm2deficient mice, we performed PCR with the following oligonucleotide primers specific for the native $\mathrm{Gcm} 2$ gene sequence and the inserted neomycin gene sequence: Gcm2-2699F (5'-CACCCTGCCAAATGGTGGATAACA-3'), Gcm2-3246R (5'-CCCTCGCATAAGTCAGCAAACATC-3'), Neo-781F ( $5^{\prime}$-TCGCCTTCTTGACGAGTTCT- $\left.3^{\prime}\right)$, and Gcm2neoR (5'-ACCTCGGCAGATGTTCAATC-3'). Amplification products were resolved by electrophoresis on a $1.5 \%$ agarose gel and visualized by ethidium bromide staining. Urine and serum biochemical measurements. Urinary deoxypyridinoline (Dpd) excretion was measured using the Pyrilinks-D assay kit (Metra Biosystems Inc., Mountain View, California, USA). Data were expressed as the ratio of $\operatorname{Dpd}(\mathrm{nm} / \mathrm{L})$ to urine creatinine $(\mu \mathrm{mol} / \mathrm{l})$. Creatinine was measured by the colorimetric alkaline picrate method (Sigma kit 555, Sigma-Aldrich, St. Louis, Missouri, USA). Serum osteocalcin levels were measured using a mouse osteocalcin IRMA kit (Immutopics, Carlsbad, California, USA). Serum PTH levels were measured by a mouse intact PTH ELISA kit (Immutopics). Calcium was measured by the colorimetric cresolphthaleinbinding method, and phosphorus was measured by the phosphomolybdate-ascorbic acid method (22).

Bone densitometry, dry ash bone weight, and skeletal radiography. Bone mineral density (BMD) of femurs was assessed at 6 weeks of age using a LUNARPIXI MUS $_{\text {bone }}$ densitometer (Lunar Corp., Madison, Wisconsin, USA). Dry ash weight of femurs collected from 1- and 6-weekold mice was measured as previously described (11).

Whole-skeleton preparation and staining. Whole mouse carcasses were collected from 1-week-old mice after euthanasia, defatted for 2-3 days in acetone, stained sequentially with Alcian blue and alizarin red S in $2 \% \mathrm{KOH}$, cleared with $1 \% \mathrm{KOH} / 20 \%$ glycerol, and stored in $50 \% \mathrm{EtOH} / 50 \%$ glycerol (11). Mice were radiographed using a HewlettPackard Faxitron 43807 and X-omat film (Eastman Kodak Co., Rochester, New York, USA).

Histomorphometric analysis of nondecalcified bone. Skeletons of mice were prelabeled with tetracycline hydrochloride
(Sigma T-7660, Sigma-Aldrich; $30 \mu \mathrm{g} / \mathrm{g}$ body weight) and calcein (Sigma C-0875, Sigma-Aldrich; $15 \mu \mathrm{g} / \mathrm{g}$ body weight) by intraperitoneal injection at days 1 and 3 in 1 -week-old mice and days 1 and 5 in 6-week-old mice before collection of tibias. Tibias were removed from 1-week-old and 6-week-old mice, fixed in 70\% ethanol, prestained in Villanueva stain, and processed for methyl methacrylate embedding. Five-micrometer sections were stained with either toluidine blue or Goldner's stain and analyzed under transmitted light, and $10-\mu \mathrm{m}$ Villanueva prestained sections were evaluated under fluorescent light as previously reported by our laboratory (11).

Statistics. We evaluated differences between groups by one-way analysis of variance. All values are expressed as means \pm SEM. All computations were performed using the Statgraphic statistical graphics system (STSC Inc., Rockville, Maryland, USA).

\section{Results}

CasR deficiency causes bypocalciuric byperparathyroidism, perinatal lethality, and rickets/osteomalacia. Compared with group I control mice, group II CasR-deficient mice had high perinatal mortality (Figure 1) in association with severe hyperparathyroidism, growth retardation, and abnormal growth-plate and bone histology (Figures 2-4 and Table 1). Most of the group II homozygous CasRdeficient mice died by the end of the first week after birth, with none of the mice surviving for more than 6 weeks (Figure 1). We observed a 28 -fold increase in serum PTH in 1-week-old group II mice (Table 1) and marked enlargement of their parathyroid glands (data not shown) as compared with normal group I controls. The elevated PTH resulted in increases in serum calcium

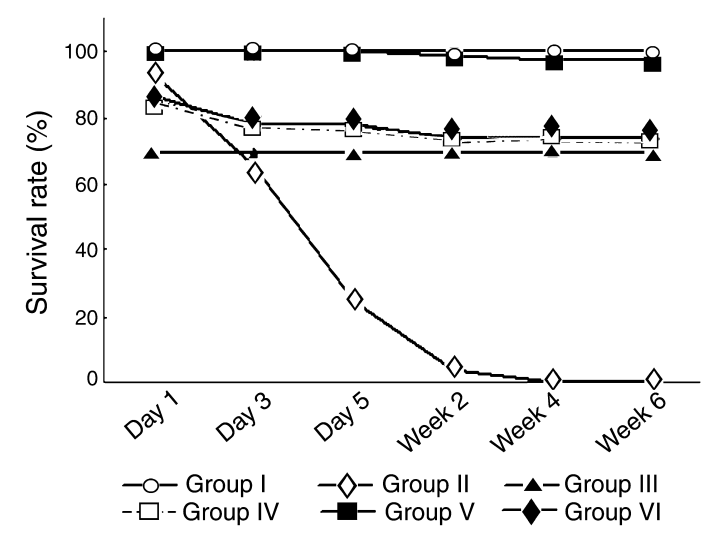

Figure 1

Survival of CasR- and Gcm2-deficient mice. The survival rate of group I, which combines data from heterozygous $\mathrm{Gcm} 2^{+/-}$and wild-type mice $(n=38)$, was $100 \%$, whereas no group II homozygous CasR-deficient mice $(n=29)$ survived beyond 3 weeks. Group III homozygous Gcm2-deficient mice $(n=13)$ had a survival rate of $69 \%$. The survival rates of group IV double homozygous CasR-and Gcm2-deficient mice $(71 \%, n=14)$ and group VI mixed heterozygous Cas $R$ - and homozygous $\mathrm{Gcm} 2$-deficient mice $(74 \%, n=23)$ are not different from that of group III Gcm $2^{-/-}$mice. Group V, which combines heterozygous $\mathrm{Cas}^{+/-}$mice and the double heterozygous $\mathrm{Gcm}^{+/-} / \mathrm{Cas}^{+/-}$ mice $(n=69)$, had a survival rate of $97 \%$. 


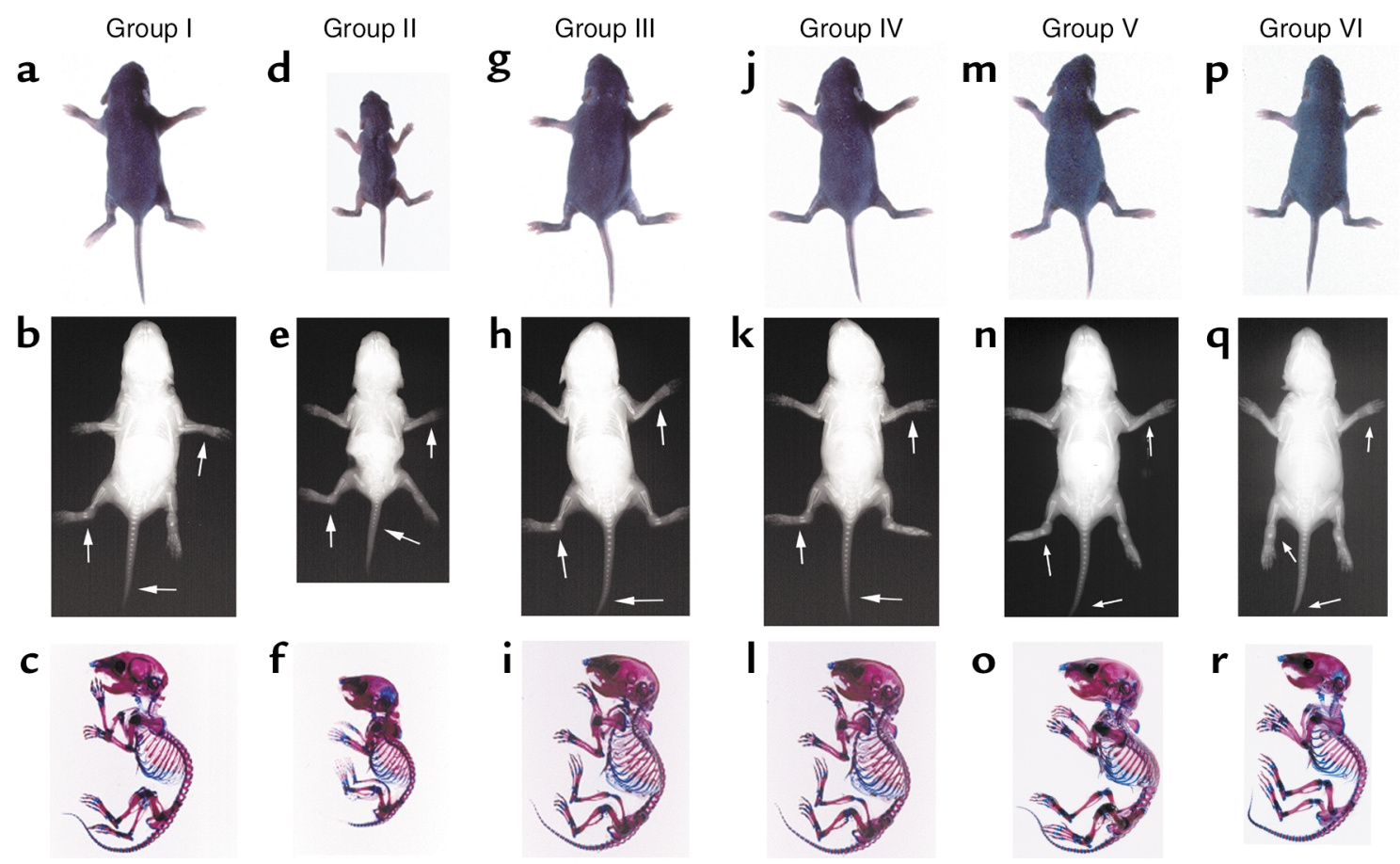

Figure 2

Skeletal phenotype of CasR- and Gcm2-deficient mice. Gross appearance ( $\mathbf{a}, \mathbf{d}, \mathbf{g}, \mathbf{j}, \mathbf{m}$, and $\mathbf{p})$, skeletal radiographs $(\mathbf{b}, \mathbf{e}, \mathbf{h}, \mathbf{k}, \mathbf{n}$, and $\mathbf{q})$, and alizarin red S/Alcian blue-stained whole skeletons $(\mathbf{c}, \mathbf{f}, \mathbf{i}, \mathbf{l}, \mathbf{o}$, and $\mathbf{r})$ of 1-week-old mice are shown. The marked reduction in body size, diffuse osteopenia, growth-plate widening (indicated by arrows), and delayed endochondral mineralization in group II homozygous Cas $R$-deficient mice are rescued by superimposed $\mathrm{Gcm} 2$ deficiency in group IV double knockout mice. The gross appearance and skeletal phenotype of groups I (normal control), III (homozygous Gcm2-deficient), IV (double homozygous CasR- and Gcm2-deficient), V (double heterozygous Cas $R$ - and Gcm2-deficient), and VI (mixed heterozygous Cas $R$ - and homozygous Gcm2-deficient mice) are indistinguishable.

and hypophosphatemia in group II CasR-deficient mice (Table 1). CasR deficiency also resulted in a twofold reduction in urinary calcium excretion, due to the absence of CasR in the kidney (Table 1).

Group II CasR-deficient mice also weighed significantly less than group I control mice and showed an obvious reduction in body size as compared with group I controls at 1 week of age (Figure 2, $d-f$ versus a-c, and Table 1). Comparison of skeletal radiographs (Figure 2, $b$ versus e), and alizarin red S/Alcian blue-stained skeletal preparations (Figure 2, c versus $\mathrm{f}$, and Figure 3, a-c versus $\mathrm{d}-\mathrm{f}$ ) of group I control littermates and group II CasR-deficient mice demonstrated that the absence of Cas $R$ results in a more radiolucent skeleton, shortened long bones, widened cartilaginous growth plates, lack of centers of secondary ossification, and delay in the mineralization of caudal vertebrae. The caudal progression of vertebral mineralization, which provides a measure of endochondral bone formation, was significantly impaired in group II CasR-deficient mice (Figures $2 \mathrm{e}$ and $3 \mathrm{f}$ and Table 1 ) as compared with group I controls (Figures $2 \mathrm{~b}$ and $3 \mathrm{c}$ and Table 1 ). The apparent decrease in mineralization of the skeleton in the group II CasR-deficient mice was further established by the significant reduction in bone ashed weight (Table 1). BMD could not be measured in 1-week-old mice because values were below the detection limit for dualenergy X-ray absorptiometry (DEXA).
The growth plate was enlarged in group II CasR-deficient mice due to the increased height of the hypertrophic zone (Figure 4, e and f) as compared with that of 1-week-old group I control mice (Figure 4, a and b). In addition, excessive amounts of osteoid were present covering trabecular bone in group II CasR-deficient mice (Figure 4g). Examination of the zone of calcified cartilage and primary spongiosa under fluorescent light in mice labeled with tetracycline and calcein demonstrated a normal pattern of mineralization in group I mice (Figure 4d) but a significant reduction in mineralized cartilage and bone in $\mathrm{Cas}^{-/-}$mice (Figure 4h). Consistent with the marked hyperparathyroidism, group II CasR-deficient mice had elevated serum osteocalcin, which is a marker of osteoblast activity, and increments in urinary excretion of Dpd, which is a marker of osteoclast activity (23) (Table 1).

Gcm2 deficiency results in the molecular ablation of parathyroid glands, mild hypoparathyroidism, and a normal-appearing skeleton. Approximately $30 \%$ of the homozygous Gcm2-deficient mice (group III) died soon after birth (Figure 1). The surviving homozygous Gcm2deficient mice were viable and developed like group I control littermates. Gcm2-deficient mice had a trend toward lower circulating PTH concentrations (group III) than control littermates (group I) at both 1 (Table 1) and 6 weeks of age (Table 2), but although the difference did not achieve statistical significance (Table 1), it was 
inappropriately low for the degree of hypocalcemia. Homozygous Gcm2-deficient mice had significantly lower serum calcium and higher serum phosphorus than group I controls (Tables 1 and 2), consistent with a functional state of PTH deficiency. Parathyroid glands could not be identified in Gcm2-deficient mice (data not shown).

Neither serum osteocalcin nor urinary Dpd levels were suppressed in group III Gcm2-deficient mice at either 1 or 6 weeks of age (Tables 1 and 2). Also, we did not identify any abnormalities of cartilage (Figure 2i; Figure 3, g-i; Figure 4, i and $j$; and Figure 5, e and f). The size and gross appearance of the skeletons of group III Gcm2-deficient mice at both 1 and 6 weeks of age were indistinguishable from those of group I normal controls (Tables 1 and 2 and Figure 2, g and $h$ versus $a$ and $b$, and Figure 3, g-i versus a-c). Gcm2-deficient mice had normal bone length, cartilaginous growth plates and centers of secondary ossification, and mineralization of caudal vertebrae as well as normal BMD. Dry ashed weight (Tables 1 and 2) and BMD by DEXA were also normal in group III mice (Table 2). Histologic evaluation revealed a normal fluorescent labeling of bone with tetracycline and calcein and osteoid-covered surfaces (Figure 41 and Figure 5, fand h).

Rescue of perinatal lethality, byperparathyroidism, and rickets/osteomalacia but not hypocalciuria in double CasR-and Gcm2-deficient mice. In group IV mice double homozygous for $C a s R$ and $G \mathrm{~cm} 2$ deficiency, $71 \%$ of the pups were alive at 6 weeks (Figure 1). Their survival curve overlapped that of group III Gcm2-deficient mice (Figure 1), indicating that CasR deficiency was no longer lethal when transferred onto the Gcm2-deficient background. Associated with the improved survival, group IV double Gcm2- and CasR-deficient mice no longer displayed evidence of hyperparathyroidism, having serum PTH, calcium, and phosphate levels not statistically different from those of group III Gcm2-deficient littermates (Tables 1 and 2). Similar to homozygous Gcm2-deficient mice, double homozygous CasR-and Gcm2-deficient mice had no detectable parathyroid glands (data not shown).

In contrast to the improved survival associated with prevention of neonatal severe hyperparathyroidism (NSHPT), transfer of CasR deficiency onto the Gcm2

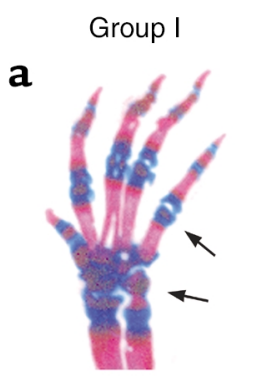

b

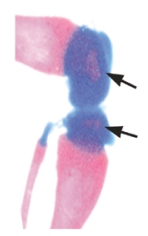

c

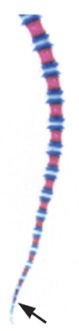

Group II

d

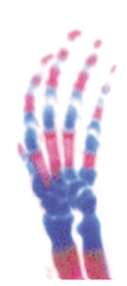

e

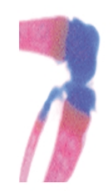

f

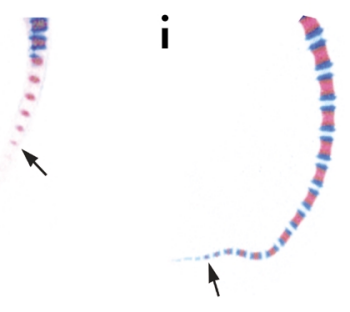

g

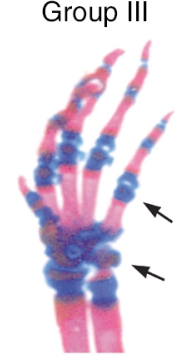

h

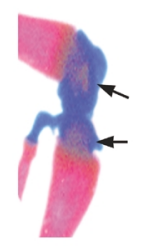

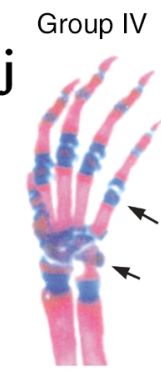

k

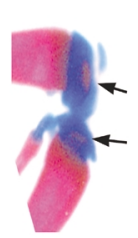

I

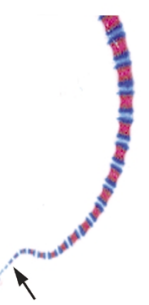

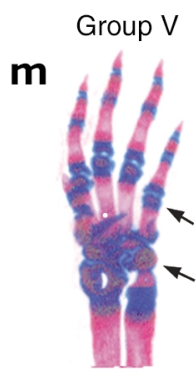

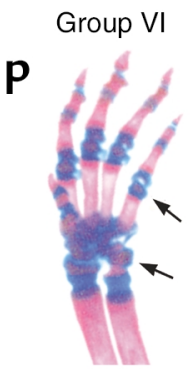

n
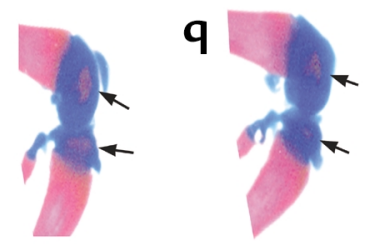

$\mathbf{0}$
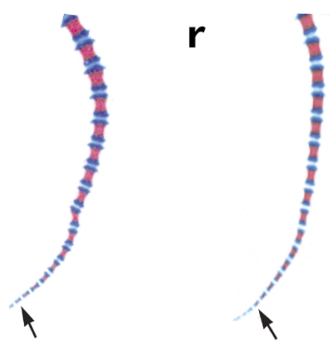

Figure 3

Alizarin red S/Alcian blue-stained skeletal regions of Cas $R$ - and Gcm2-deficient mice. (a-c) Heterozygous Gcm2 ${ }^{+/-}$and wild-type mice. (d-f) Homozygous CasR-deficient mice. ( $\mathbf{g}$-i) Homozygous Gcm2-deficient mice. (j-I) Double homozygous CasR-and Gcm2-deficient mice. (m-o) Heterozygous $\mathrm{Cas}^{+/-}$and double heterozygous $\mathrm{Gcm} 2^{+/-} / \mathrm{Cas}^{+/-}$mice. (p-r) Heterozygous Cas $R^{+/-}$and homozygous Gcm2-deficient mice. Normal appearance of the wrist from a group I control mouse (a) is compared to the widening of the growth plate of the wrist in a 1-weekold group II homozygous CasR-deficient littermate (d). These abnormalities are rescued in group IV double knockout mice (j) and are not present in the other groups $(\mathbf{g}, \mathbf{m}$, and $\mathbf{p})$. Mineralization in the epiphysis cartilage of the femur is present in group I control mice (b) but not in the Cas $R^{-1-}$ mice (e). Secondary centers of ossification are restored in group IV homozygous Cas $R$ - and Gcm2-deficient mice (k). No abnormalities of ossification centers were observed in the other groups (h, $\mathbf{n}$, and $\mathbf{q})$. Endochondral mineralization, as assessed by the number of alizarin red-positive mineralized caudal vertebrae, is reduced in 1-week-old group II Cas $R^{-/-}$mice (f) as compared with group I controls (c), whereas group IV homozygous CasR-and $\mathbf{G c m} 2$-deficient mice (I) as well as the other groups (i, $\mathbf{o}$, and $\mathbf{r})$ show the same number of alizarin red-positive mineralized caudal vertebrae, consistent with a normal temporal and spatial pattern of endochondral bone formation. 


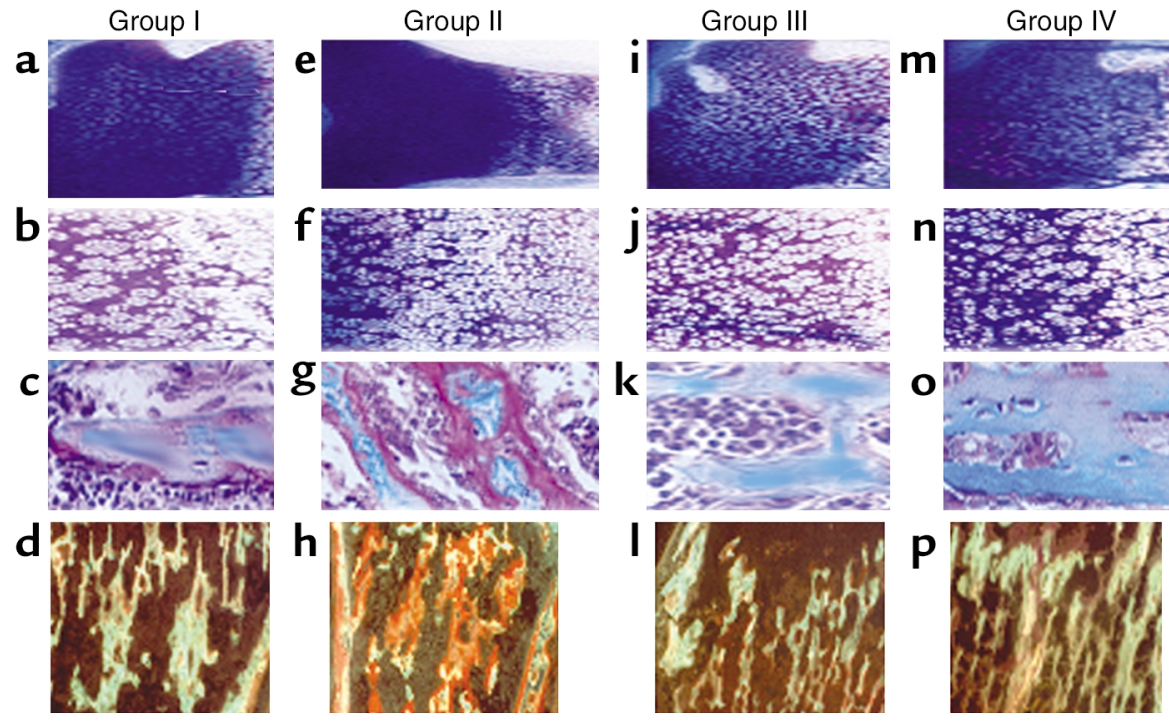

Figure 4

Nondecalcified histologic sections of the tibia of 1-week-old CasR- and Gcm2-deficient mice. Shown are group I controls (a-d), group II CasR-deficient mice $(\mathbf{e}-\mathbf{h})$, group III Gcm2-deficient mice (i-I), and group IV double homozygous CasR-and Gcm2-deficient mice ( $\mathbf{m}-\mathbf{p})$. A toluidine blue-stained section of the growth plate $(\times 125$ in $\mathbf{a}, \mathbf{e}, \mathbf{i}$, and $\mathbf{m}$ and $\times 250$ in $\mathbf{b}, \mathbf{f}, \mathbf{j}$, and $\mathbf{n})$ shows a widened zone of hypertrophic chondrocytes in group II CasR-deficient mice that was corrected in group IV double homozygous CasR- and Gcm2-deficient mice, which were indistinguishable from group I and group III mice. A higher-power view of Goldner-stained sections ( $\times 500$ in $\mathbf{c}, \mathbf{g}, \mathbf{k}$, and $\mathbf{o})$ of trabecular bone in secondary spongiosa. Excess osteoid is present in group II CasR $R^{-1-}$ mice $(\mathbf{g})$ and resolution of hyperosteoidosis in group IV double knockout mice (o). In Goldner-stained sections, mineralized bone is blue and unmineralized osteoid is reddish-brown in color. The view under fluorescent light of Villanueva-stained sections of metaphysis ( $\times 500$ in $\mathbf{d}, \mathbf{h}, \mathbf{I}$, and $\mathbf{p}$ ) showing the attenuation of calcein deposition in the primary and secondary spongiosa of group II CasR-deficient mice $(\mathbf{h})$ is normalized in group IV double knockout mice (p).

null background did not rescue the hypocalciuria, which defines the kidney phenotype of CasR deficiency in the renal tubules. In this regard, the urinary calci$\mathrm{um} /$ creatinine ratio, which was normal in group III Gcm2-deficient mice and suppressed in group II CasRdeficient mice, remained diminished in group IV double Gcm2- and CasR-deficient mice at both 1 and 6 weeks of age (Tables 1 and 2).

Transfer of CasR deficiency onto the Gcm2 null background, however, rescued the rickets and osteomalacia associated with CasR deficiency. The size and gross appearance of group IV mice double homozygous for Cas $R$ and $G \mathrm{~cm} 2$ deficiency at both 1 and 6 weeks of age were indistinguishable from those of group I control and group III Gcm2-deficient mice (Figure 2 and Tables 1 and 2), indicating that the effect of CasR deficiency on the gross appearance of the skeleton was corrected on the Gcm2-deficient background. In spite of the absence of CasR, group IV double knockout mice also had normal bone density and bone length (Table 2). The rachitic changes disappeared in double knockout mice as evidenced by the normal growth plates, centers of secondary ossification, and mineralization of caudal vertebrae (Figure 2, j-1, and Figure 3, j-1). Histologic examination of cartilage confirmed the correction of the widened zone of hypertrophic chondrocytes and the 1 and 6 weeks of age (Tables 1 and 2). Serum calcium and phosphorus in group $\mathrm{V}$ mice did not differ from values in group I controls in spite of a twofold increase in PTH levels at 6 weeks of age. Serum osteocalcin but not DPD levels were increased in 6-week-old group V mice (Table 2), consistent with the effect of increased PTH on bone. The skeletons of 1- and 6-week-old heterozygous CasRdeficient mice, however, were indistinguishable from those of controls as assessed by skeletal radiography (Figure 2, n versus b), whole skeletal mounts (Figure 2, o versus $\mathrm{c}$, and Figure 3, m-o versus a-c), bone ashed weight and BMD (Table 2), and bone histology (Figure 5 , o and $\mathrm{p}$ versus $\mathrm{c}$ and d). In group VI heterozygous CasR- and Gcm2-deficient mice, superimposed Gcm2 deficiency predominated over that of heterozygous Cas $R$ deficiency, leading to a reduced survival (Figure 1), low PTH, and hypocalcemia (Tables 1 and 2). Consistent with the similar biochemical profiles, the growth plate and calcified cartilage in group V heterozygous Cas $R$ deficient mice were also indistinguishable from those of group I normal mice at 6 weeks of age (Figure 5, q- $t$ ).

\section{Discussion}

In the current study, we created a molecular parathyroidectomy in CasR-deficient mice by transferring Cas $R$ deficiency onto the Gcm 2 null background in order to 
assess the independent role that Cas $R$ deficiency plays in the abnormalities of cartilage and bone. We found that $\mathrm{Gcm} 2$ deficiency exerted a dominant effect to prevent the development of parathyroid glands in CasRdeficient mice, thereby replacing severe hyperparathyroidism with a state of mild hypoparathyroidism (Tables 1 and 2 ) due to the accessory production of PTH (19). Correction of the metabolic abnormalities was sufficient to rescue the perinatal lethality of Cas $R$ deficiency (Tables 1 and 2). In this regard, double homozygous CasR-and Gcm2-deficient mice, rather than dying in the early neonatal period as occurs with Cas $R$ deficiency, had survival rates indistinguishable from those of Gcm2-deficient littermates (Figure 1).

The survival of double CasR-and Gcm2-deficient mice permitted the role of CasR to be assessed in the adult mouse skeleton and in other tissues where the function of Cas $R$ remains uncertain. Analysis of 1- and 6-weekold mice demonstrated that transfer of CasR deficiency onto the Gcm 2 null background also corrected growth retardation and skeletal abnormalities associated with CasR deficiency (Figures 2-5). The bone length, width of the growth plates, centers of ossification, and bone mineral density were indistinguishable among Gcm2-deficient mice, CasR-and Gcm2-deficient mice, and normal mice. Histologic analysis of nondecalcified cartilage and bone also demonstrated that the increased zone of hypertrophic cartilage, hyperosteoidosis, and mineralization abnormalities had resolved (Figures 4 and 5). These results are consistent with the observation that parathyroidectomy in humans with NSHPT apparently cures the skeletal abnormalities $(24,25)$. In contrast to the rescue of the bone and cartilage phenotype of CasR-deficient mice, hypocalciuria remained in double CasR-and Gcm2-null mice (Tables 1 and 2), indicating that the manifestation of CasR loss on renal tubular excretion of calcium was not rescued (1). The fact that the effects of Cas $R$ deficiency remain at sites where the receptor plays a physiological role adds further support to the conclusion that the absence of skeletal Cas $R$ is not responsible for rickets and osteomalacia in CasR-deficient mice.

The rescue of the skeletal phenotype by ablation of the parathyroid glands in double CasR-and Gcm2-deficient mice indicates that excessive $\mathrm{PTH}$, when combined with rapid skeletal growth during the neonatal period, is predominantly responsible for rickets and osteomalacia. The ability of parathyroid gland ablation to rescue the rickets and osteomalacia in CasR-deficient mice is surprising, since excess PTH typically leads to increased

Table 2

Data from 6-week old mice

\begin{tabular}{|c|c|c|c|c|c|c|c|}
\hline Group & 1 & II & III & IV & V & $\mathrm{VI}$ & $P$ value \\
\hline Genotype & $\begin{array}{c}+/+ \\
+/+ \text { or }+/-\end{array}$ & $\begin{array}{c}-/- \\
+/+ \text { or }+/-\end{array}$ & $\begin{array}{l}+/+ \\
-/-\end{array}$ & $\begin{array}{l}-1- \\
-1-\end{array}$ & $\begin{array}{c}+/- \\
+/+ \text { or }+/-\end{array}$ & $\begin{array}{l}+/- \\
-/-\end{array}$ & \\
\hline \multicolumn{8}{|l|}{ Serum values } \\
\hline PTH (pg/ml) & $\begin{aligned} 26 & \pm 3.5^{B} \\
(n & =27)\end{aligned}$ & - & $\begin{array}{c}17 \pm 2.8^{\mathrm{A}, \mathrm{B}} \\
(n=8)\end{array}$ & $\begin{array}{c}12 \pm 1.3^{\mathrm{A}} \\
(n=10)\end{array}$ & $\begin{array}{c}40 \pm 5.0^{C} \\
(n=21)\end{array}$ & $\begin{array}{c}10 \pm 1.2^{\mathrm{A}} \\
(n=17)\end{array}$ & $<0.001$ \\
\hline Calcium (mg/dl) & $\begin{array}{c}8.1 \pm 0.1^{\mathrm{B}} \\
(n=27)\end{array}$ & - & $\begin{array}{c}6.3 \pm 0.4^{\mathrm{A}} \\
(n=8)\end{array}$ & $\begin{array}{c}6.0 \pm 0.3^{\mathrm{A}} \\
(n=10)\end{array}$ & $\begin{array}{c}8.6 \pm 0.1^{\mathrm{B}} \\
(n=21)\end{array}$ & $\begin{array}{c}5.7 \pm 0.3^{\mathrm{A}} \\
(n=17)\end{array}$ & $<0.001$ \\
\hline Phosphorus (mg/dl) & $\begin{array}{c}8.2 \pm 0.3^{\mathrm{A}} \\
(n=27)\end{array}$ & - & $\begin{array}{c}13.2 \pm 1.0^{\mathrm{B}} \\
(n=8)\end{array}$ & $\begin{array}{c}14.8 \pm 0.9^{\mathrm{B}} \\
(n=10)\end{array}$ & $\begin{array}{c}8.2 \pm 0.3^{\mathrm{A}} \\
(n=21)\end{array}$ & $\begin{array}{c}14.0 \pm 0.6^{\mathrm{B}} \\
(n=17)\end{array}$ & $<0.001$ \\
\hline Osteocalcin (ng/ml) & $\begin{array}{c}285 \pm 19^{\mathrm{A}} \\
(n=13)\end{array}$ & - & $\begin{array}{c}275 \pm 41^{\mathrm{A}} \\
(n=5)\end{array}$ & $\begin{array}{c}265 \pm 37^{A} \\
(n=6)\end{array}$ & $\begin{array}{c}398 \pm 42^{\mathrm{B}} \\
(n=8)\end{array}$ & $\begin{array}{c}256 \pm 33^{\mathrm{A}} \\
(n=33)\end{array}$ & 0.028 \\
\hline \multicolumn{8}{|l|}{ Urine values } \\
\hline Dpd/creatinine ratio & $\begin{array}{c}23 \pm 3 \\
(n=16)\end{array}$ & - & $\begin{array}{l}28 \pm 7 \\
(n=5)\end{array}$ & $\begin{array}{l}21 \pm 4 \\
(n=5)\end{array}$ & $\begin{array}{l}28 \pm 4 \\
(n=8)\end{array}$ & $\begin{array}{l}20 \pm 4 \\
(n=7)\end{array}$ & 0.695 \\
\hline Calcium/creatinine ratio & $\begin{array}{c}0.6 \pm 0.05^{\mathrm{B}, \mathrm{C}} \\
(n=34)\end{array}$ & - & $\begin{array}{c}0.8 \pm 0.1^{C} \\
(n=8)\end{array}$ & $\begin{array}{c}0.4 \pm 0.07^{\mathrm{A}} \\
(n=9)\end{array}$ & $\begin{array}{c}0.5 \pm 0.08^{\mathrm{A}, \mathrm{B}} \\
(n=11)\end{array}$ & $\begin{array}{c}0.4 \pm 0.04^{\mathrm{A}} \\
(n=13)\end{array}$ & 0.005 \\
\hline \multicolumn{8}{|l|}{ Structural parameters } \\
\hline \multicolumn{8}{|l|}{ Body weight $(\mathrm{g})$} \\
\hline Male & $\begin{array}{c}24.3 \pm 0.05 \\
(n=16)\end{array}$ & - & $\begin{array}{c}23.5 \pm 0.8 \\
(n=4)\end{array}$ & $\begin{array}{c}23.5 \pm 1.0 \\
(n=6)\end{array}$ & $\begin{array}{c}24.4 \pm 0.3 \\
(n=32)\end{array}$ & $\begin{array}{c}23.2 \pm 0.7 \\
(n=11)\end{array}$ & 0.429 \\
\hline Female & $\begin{array}{c}19.3 \pm 0.4 \\
(n=22)\end{array}$ & - & $\begin{array}{c}19.1 \pm 1.3 \\
(n=5)\end{array}$ & $\begin{array}{c}19.9 \pm 1.2 \\
(n=4)\end{array}$ & $\begin{array}{c}20.2 \pm 0.4 \\
(n=35)\end{array}$ & $\begin{array}{c}19.6 \pm 1.6 \\
(n=6)\end{array}$ & 0.728 \\
\hline Body length (mm) & $\begin{array}{c}81.6 \pm 0.7 \\
(n=35)\end{array}$ & - & $\begin{array}{c}80.9 \pm 1.4 \\
(n=9)\end{array}$ & $\begin{array}{c}80.8 \pm 1.3 \\
(n=10)\end{array}$ & $\begin{array}{c}83.3 \pm 0.4 \\
(n=56)\end{array}$ & $\begin{array}{c}82.8 \pm 1.2 \\
(n=17)\end{array}$ & 0.101 \\
\hline Femur length (mm) & $\begin{array}{c}12.6 \pm 0.1 \\
(n=35)\end{array}$ & - & $\begin{array}{c}12.6 \pm 0.2 \\
(n=9)\end{array}$ & $\begin{array}{c}12.4 \pm 0.1 \\
(n=10)\end{array}$ & $\begin{array}{c}12.6 \pm 0.1 \\
(n=56)\end{array}$ & $\begin{array}{c}12.4 \pm 0.1 \\
(n=17)\end{array}$ & 0.542 \\
\hline Bone ash (\% dry wt) & $\begin{array}{c}59.6 \pm 0.3 \\
(n=38)\end{array}$ & - & $\begin{array}{c}60.2 \pm 0.4 \\
(n=9)\end{array}$ & $\begin{array}{c}59.0 \pm 0.5 \\
(n=10)\end{array}$ & $\begin{array}{c}59.3 \pm 0.2 \\
(n=67)\end{array}$ & $\begin{array}{c}60.2 \pm 0.9 \\
(n=17)\end{array}$ & 0.339 \\
\hline $\operatorname{BMD}\left(\mathrm{g} / \mathrm{cm}^{2}\right)$ & $\begin{array}{c}0.059 \pm 0.001 \\
(n=38)\end{array}$ & - & $\begin{array}{c}0.061 \pm 0.003 \\
(n=9)\end{array}$ & $\begin{array}{c}0.06 \pm 0.002 \\
(n=10)\end{array}$ & $\begin{array}{c}0.061 \pm 0.001 \\
(n=67)\end{array}$ & $\begin{array}{c}0.06 \pm 0.002 \\
(n=17)\end{array}$ & 0.850 \\
\hline
\end{tabular}

Values represent mean \pm SEM of the number of animals per group as indicated in parentheses. None of the Group II animals survived 6 weeks. A,B,CIndicates significant differences. Values sharing the same superscript or lacking superscripts in a given category are not significantly different, whereas those having a different superscript are significantly different at indicated $P$ values at the end of the row. Groups are the same as described in Table 1 . BMD, bone mineral density. Other abbreviations are the same as in Table1. 
a
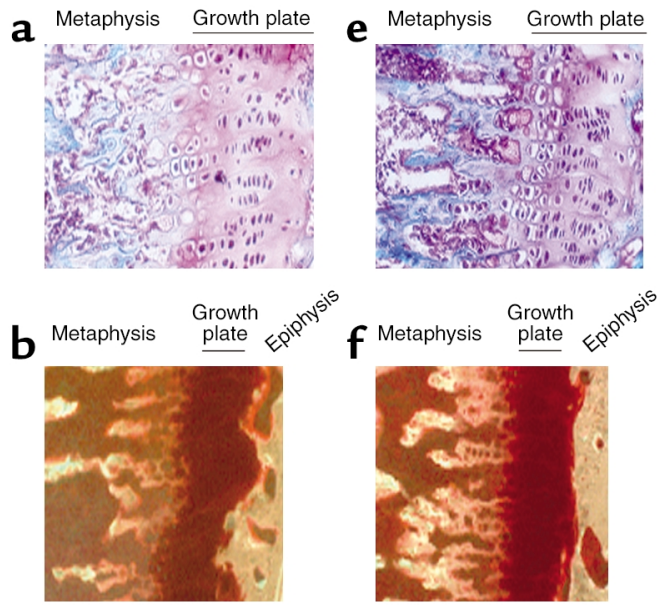

C

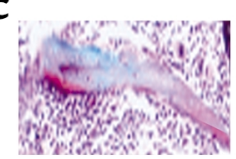

d
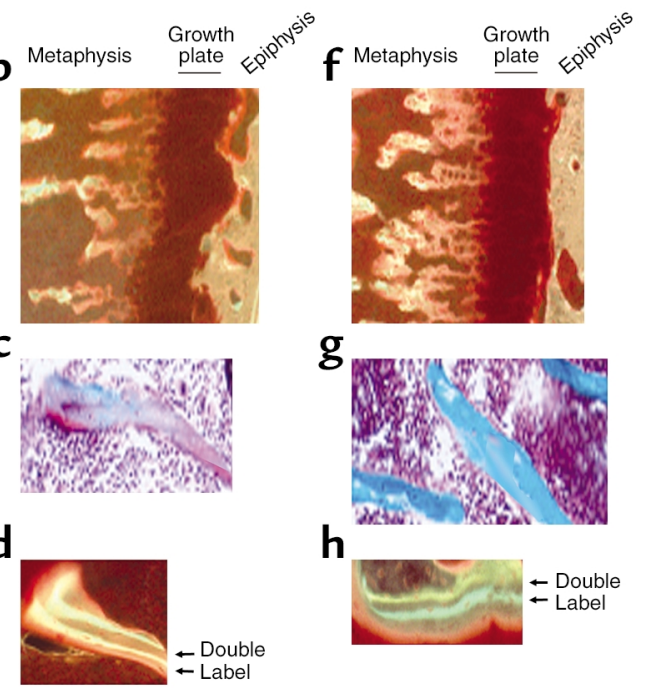

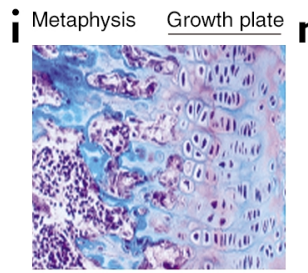

m

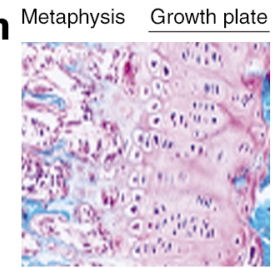

k
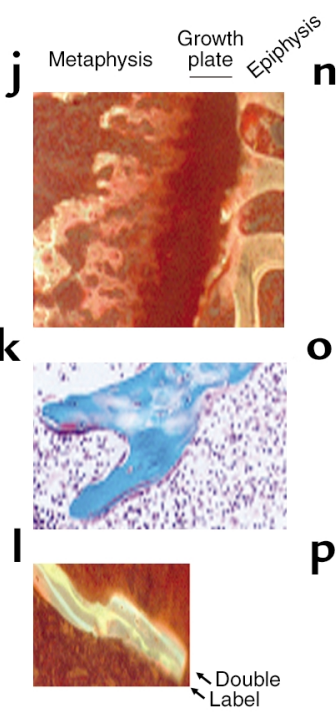
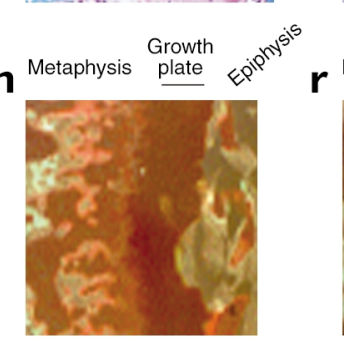

o

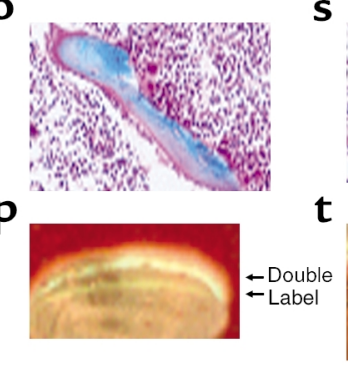

t
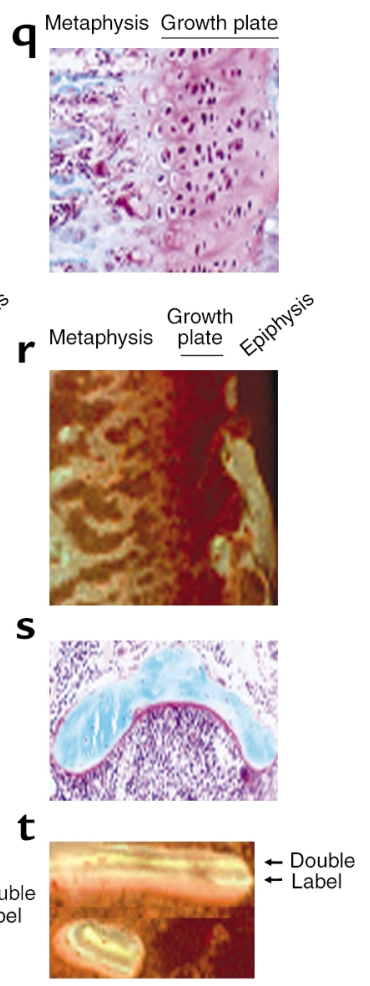

\section{Figure 5}

Histologic analysis of the growth plate and bone of 6-week-old homozygous and heterozygous CasR-and Gcm2-deficient mice. Shown are group I normal controls (a-d), group III homozygous Gcm2-deficient mice (e-h), group IV double homozygous Cas $R$ - and Gcm2-deficient mice $(\mathbf{i}-\mathbf{I})$, group V heterozygous Gcm2-deficient mice ( $\mathbf{m}-\mathbf{p})$, and group VI heterozygous Cas $R$ - and Gcm2-deficient mice ( $\mathbf{q}-\mathbf{t})$. Goldner-stained sections $(\times 250$ in $\mathbf{a}, \mathbf{e}, \mathbf{i}, \mathbf{m}$, and $\mathbf{q})$ show normal growth plates in all groups. Villanueva-stained sections $(\times 125$ in $\mathbf{b}, \mathbf{f}, \mathbf{j}, \mathbf{n}$, and $\mathbf{r})$ of the growth plate and adjacent metaphysis show normal mineralization of primary and secondary spongiosa in all groups. Goldner-stained sections $(\times 500$ in $\mathbf{c}, \mathbf{g}, \mathbf{k}, \mathbf{o}$, and $\mathbf{s})$ show normal amounts of osteoid in all groups. A highly magnified view $(\times 500 \mathrm{in} \mathbf{d}, \mathbf{h}, \mathbf{l}, \mathbf{p}$, and $\mathbf{t})$ of trabecular bone under fluorescent light reveals normal mineralization in all groups as evidenced by dual calcein and tetracycline labels on the bone surfaces.

bone turnover and accelerated mineralization in adults (11). However, the skeletal phenotype associated with gain-of-function mutations of PTH/PTH related peptide targeted to cartilage has some similarities to the skeletal phenotype of CasR deficiency (26). The intensity and persistence of activation of the PTH signal-transduction pathway might explain these differences in the skeletal phenotype induced by increased PTH secretion in CasR-deficient mice, which could lead to matrix biosynthesis in cartilage and bone in excess of the capacity to mineralize or production of mineralization inhibitors, such as matrix $\gamma$-carboxyglutamic acid protein from osteoblasts, as demonstrated in vitro (27). Indeed, the current findings add further support to an important role of hyperparathyroidism in the development of rickets and osteomalacia in vitamin D-deficient rats and vitamin D receptor-deficient mice (28, 29). Hypophosphatemia also does not seem to be sufficient to account for the skeletal phenotype in CasR-deficient mice. In this regard, $N p t 2$ null mice, which are hypophosphatemic due to the absence of the sodiumphosphate transporter in the proximal tubule, exhibit only mild retardation of secondary ossification and minimal growth-plate abnormalities $(30,31)$ and do not manifest overt signs of rickets and osteomalacia.
Although the current studies fail to support an essential and nonredundant role of CasR in normal cartilage and bone development, they do not prove the lack of function of CasR in bone/cartilage formation. Since in vitro data are consistent with a functional role for Cas $R$ or a related extracellular calcium-sensing mechanism in chondrocytes and bone marrow (5), it is possible that low calcium and/or hypoparathyroidism could have masked the effects of CasR to regulate cartilage and bone function. Further studies are needed to compare the skeletal phenotypes of Gcm2-deficient and double homozygous CasR-and Gcm2-deficient mice after normalization of calcium and PTH. In addition, long-term observation of double homozygous CasR-and Gcm2-deficient mice and provocative studies with calcimimetics may be needed to uncover effects of Cas $R$ on cartilage and bone function. The presence of redundant calcium-sensing mechanisms due to other calcium-sensing receptors and/or membrane channels provides another explanation for the lack of apparent in vivo CasR function in the skeleton (14). Indeed, there is an ongoing controversy as to whether all of the functional responses to cations in osteoblasts and osteoclasts are mediated solely by CasR or whether another Cas $R$-like receptor is present that differs from Cas $R$ with regard to cation specificity, response to calcimimetics, and 
signaling pathways $(11,13)$. It is possible that the severe hypercalcemia acting through another calcium-sensing receptor or mechanism might contribute to skeletal changes in Cas $R$-deficient mice. In this regard, aluminum, which stimulates the putative novel cation-sensing receptor in osteoblasts but not CasR (14), causes osteomalacia in both humans and animal models $(15,32)$. Finally, since the genetic background can influence the severity of any given phenotype, it is possible that the mixed background of CasR-and Gcm-deficient mice might have obscured the effect of CasR deficiency on bone and cartilage. Although we did not observe major strain-specific variations in cartilage and bone formation in this study, it may be important to evaluate the skeletal effect of Cas $R$ deficiency in different genetic backgrounds.

The current studies provide additional insights into the role of Cas $R$ and age in the phenotype of $\mathrm{Gcm} 2$-deficient mice. Consistent with previous reports of maximal stimulation of PTH secretion by CasR at extraparathyroid sites (19), we failed to see further compensatory increases in PTH levels with superimposed CasR deficiency. Unlike previously reported data from 6-month-old mice (19), we found no demonstrable effects of $\mathrm{Gcm} 2$ deficiency on biochemical markers of bone turnover, bone ashed weight, $\mathrm{BMD}$, or bone histology in 6-week-old mice. The failure to observe these skeletal abnormalities in 6-week old mice might be due to compensatory factors associated with skeletal growth in young mice.

In conclusion, correction of severe hyperparathyroidism and the accompanying hypercalcemia and hypophosphatemia is sufficient to correct the abnormalities of mineralization of the extracellular matrix in Cas $R$-deficient mice. The rescue of the skeletal phenotype fails to support an essential role for CasR in cartilage and bone, but long-term studies and additional in vivo and in vitro experiments are needed to define the role of CasR in bone and cartilage as well as at other sites. The rescue of the perinatal lethality of CasR null mice by backcrossing onto the $\mathrm{Gcm} 2$-deficient background should provide a useful model for evaluation of the role Cas $R$ in regulating the physiological functions of other organs and tissues where it is expressed, without the confounding effects of excess PTH.

\section{Acknowledgments}

This work was supported by National Institutes of Arthritis and Musculoskeletal and Skin Disorders grant R01-AR-37308 from the NIH. The authors would like to thank Cristy McGranahan for secretarial assistance with preparation of this manuscript.

1. Brown, E.M., and MacLeod, R.J. 2001. Extracellular calcium sensing and extracellular calcium signaling. Physiol. Rev. 81:239-297.

2. Brown, E.M., et al. 1993. Cloning and characterization of an extracellular $\mathrm{Ca}^{2+}$-sensing receptor from bovine parathyroid. Nature. 366:575-580.

3. Pollak, M.R., et al. 1993. Mutations in the human $\mathrm{Ca}^{2+}$-sensing receptor gene cause familial hypocalciuric hypercalcemia and neonatal severe hyperparathyroidism. Cell. 75:1297-1303.

4. Bai, M., et al. 1996. Expression and characterization of inactivating and activating mutations in the human $\mathrm{Ca}^{2+} \mathrm{O}$-sensing receptor. J. Biol. Chem. 271:19537-19545.

5. Shoback, D., and Chang, W. 2001. Starvation amidst plenty - rickets and hypercalcemia in calcium receptor knockout mice. Endocrinology. 142:3733-3735.

6. Chang, W., Tu, C., Pratt, S., Chen, T.H., and Shoback, D. 2002. Extracellular $\mathrm{Ca}^{2+}$-sensing receptors modulate matrix production and mineralization in chondrogenic RCJ3.1C5.18 cells. Endocrinology. 143:1467-1474.

7. House, M.G., et al. 1997. Expression of an extracellular calcium-sensing receptor in human and mouse bone marrow cells. J. Bone Min. Res. 12:1959-1970.

8. Yamaguchi, T., Chattopadhyay, N., Kifor, O., and Brown, E.M. 1998. Extracellular calcium $\left(\mathrm{Ca}^{2+}(\mathrm{o})\right)$-sensing receptor in a murine bone marrowderived stromal cell line (ST2): potential mediator of the actions of $\mathrm{Ca}^{2+}(\mathrm{o})$ on the function of ST2 cells. Endocrinology. 139:3561-3568.

9. Yamaguchi, T., et al. 1988. Mouse osteoblastic cell line (MC3T3-E1) expresses extracellular calcium $\left(\mathrm{Ca}^{2+} \mathrm{O}\right)$-sensing receptor and its agonists stimulate chemotaxis and proliferation of MC3T3-E1 cells. J. Bone Miner. Res. 13:1530-1538.

10. Chang, W., et al. 1999. Calcium sensing in cultured chondrogenic RCJ3.1C5.18 cells. Endocrinology. 140:1911-1919.

11. Garner, S.C., Pi, M., Tu, Q., and Quarles, L.D. 2001. Rickets in cation-sensing receptor-deficient mice: an unexpected skeletal phenotype. Endocrinology. 142:3996-4005.

12. Quarles, L.D., Hartle, J.E., II, Siddhanti, S.R., Guo, R., and Hinson, T.K. 1997. A distinct cation-sensing mechanism in MC3T3-E1 osteoblasts functionally related to the calcium receptor. J. Bone Miner. Res. 12:393-402.

13. Pi, M., Hinson, T.K., and Quarles, L.D. 1999. Failure to detect the extracellular calcium sensing receptor (CasR) in human osteoblast cell lines. J. Bone Miner. Res. 14:1310-1319.

14. Pi, M., Garner, S.C., Flannery, P.J., Spurney, R.F., and Quarles, L.D. 2000. Sensing of extracellular cations in CasR-deficient osteoblasts: evidence for a novel cation-sensing mechanism. J. Biol. Chem. 275:3256-3263.

15. Quarles, L.D., Gitelman, H.J., and Drezner, M.K. 1988. Induction of de novo bone formation in the beagle. A novel effect of aluminum. J. Clin. Invest. 81:1056-1066.

16. Kovacs, C.S., et al. 1998. Regulation of murine fetal-placental calcium metabolism by the calcium-sensing receptor. J. Clin. Invest. 101:2812-2820.

17. Miao, D., He, B., Karaplis, A.C., and Goltzman, D. 2002. Parathyroid hormone is essential for normal fetal bone formation. J. Clin. Invest. 109:1173-1182. doi:10.1172/JCI200214817.

18. Kim, J., et al. 1998. Isolation and characterization of mammalian homologs of the Drosophila gene glial cells missing. Proc. Natl. Acad. Sci. U. S. A. 95:12364-12369.

19. Gunther, T., et al. 2000. Genetic ablation of parathyroid glands reveals another source of parathyroid hormone. Nature. 406:199-203.

20. Ho, C., et al. 1995. A mouse model of human familial hypocalciuric hypercalcemia and neonatal severe hyperparathyroidism. Nat. Genet. 11:389-394.

21. Oda, Y., et al. 2000. The calcium sensing receptor and its alternatively spliced form in murine epidermal differentiation. J. Biol. Chem. 275:1183-1190

22. Morin, L.G. 1974. Direct colorimetric determination of serum calcium with o-cresolphthalein complexion. Am. J. Clin. Pathol. 61:114-117.

23. Jilka, R.L., et al. 1998. Loss of estrogen upregulates osteoblastogenesis in the murine bone marrow. Evidence for autonomy from factors released during bone resorption. J. Clin. Invest. 101:1942-1950.

24. Lutz, P., et al. 1986. Neonatal primary hyperparathyroidism: total parathyroidectomy with autotransplantation of cryopreserved parathyroid tissue. Acta Paediatr. Scand. 75:179-182.

25. Fujimoto, Y., Hazama, H., and Oku, K. 1990. Severe primary hyperparathyroidism in a neonate having a parent with hypercalcemia: treatment by total parathyroidectomy and simultaneous heterotopic autotransplantation. Surgery. 108:933-938.

26. Schipani, E., et al. 1997. Targeted expression of constitutively active receptors for parathyroid hormone and parathyroid hormone-related peptide delays endochondral bone formation and rescues mice that lack parathyroid hormone-related peptide. Proc. Natl. Acad. Sci. U. S. A. 94:13689-13694.

27. Gopalakrishnan, R., Ouyang, H., Somerman, M.J., McCauley, L.K., and Franceschi, R.T. 2001. Matrix gamma-carboxyglutamic acid protein is a key regulator of PTH-mediated inhibition of mineralization in MC3T3E1 osteoblast-like cells. Endocrinology. 142:4379-4388.

28. Underwood, J., and DeLuca, H. 1984. Vitamin D is not directly necessary for bone growth and mineralization. Am. J. Physiol. 246:E493-E498.

29. Li, Y., et al. 1998. Normalization of mineral ion homeostasis by dietary means prevents hyperparathyroidism, rickets, and osteomalacia, but not alopecia in vitamin D receptor-ablated mice. Endocrinology. 139:4391-4396.

30. Beck, L., et al. 1998. Targeted inactivation of Npt2 in mice leads to severe renal phosphate wasting, hypercalciuria and skeletal abnormalities. Proc. Natl. Acad. Sci. U. S. A. 95:5372-5377.

31. Gupta, A., et al. 2001. Identification of the type II Na( $\left(^{+}\right)$-Pi cotransporter $(\mathrm{Npt} 2)$ in the osteoclast and the skeletal phenotype of $\mathrm{Npt}^{-/-}$mice. Bone. 29:467-476.

32. Spurney, R.F., Pi, M., Flannery, P., and Quarles, L.D. 1999. Aluminum is a weak agonist for the calcium sensing receptor. Kidney Int. 55:1750-1758. 